\title{
Indole Alkaloids from Rauvolfia reflexa (Apocynaceae)
}

\author{
Mehran Fadaeinasab ${ }^{1, *}$, A. Hamid A. Hadi ${ }^{1}$, Masoumeh Hoseinzadeh ${ }^{1}$ and Hiroshi Morita ${ }^{2}$ \\ ${ }^{I}$ Department of Chemistry, Faculty of Science, 50603 University Malaya, Kuala Lumpur \\ ${ }^{2}$ Faculty of Pharmaceutical Sciences, Hoshi University, Ebara 2-4-41 Shinagawa, Tokyo 142-8501, Japan
}

\begin{abstract}
From the methanolic crude extract of Rauvolfia reflexa six indole alkaloids were isolated namely; (1), akuammilan (2), vomilenine (3), isoresrpiline (4), rescinnamine (5), and cantleyine (6). The methanol crude extract showed moderate anticancer activity against MCF-7 and WRL-68 cell lines, although the isolated compounds and dichloromethane crude extract were also tested for anticancer activity but they didn't show significant activity against MCF-7 and WRL-86 cancer cell lines.
\end{abstract}

Keywords: Alkaloids, anti cancer activity, Apocynaceae, Rauvolfia, NMR.

\section{INTRODUCTION}

Bioactive indole alkaloids have been isolated from Rauvolfia reflexa (Apocynaceae). The chemistry of the Rauvolfia species has been comprehensively investigated for the presence of alkaloids over a long period of time [1]. First part of research program was on the occurrence of alkaloids in Malaysian species of Rauvolfia, a phytochemical analysis from bark of Rauvolfia reflexa is described. Six alkaloids were isolated; the structures of all alkaloids isolated were determined by a detailed analysis of the ${ }^{1} \mathrm{H} N M R,{ }^{13} \mathrm{C} N M R$, HMBC, HSQC, NOESY, COSY spectral data and confirmed by UV, IR and MS. Second part of research was carried out In vitro studies of the crude extracts and pure compounds isolated from Rauvolfia reflexa which the methanolic crude extracts exhibited considerable anticancer Activity.

\section{RESULTS AND DISCUSSION}

Plant material was collected at Kelantan, and air-dried. The methanol crude extract, from the bark, were submitted to acid-base treatment and fractions corresponding to different $\mathrm{pH}$ ranges were purified by flash-chromatography, LH-20 sephadex and preparative TLC, leading to the isolation of six indole alkaloids (Fig. 1). Undulifoline (1) [2], akuammilan (2) [3], vomilenine (3) [4], isoresrpiline (4) [5], rescinnamine (5) [6], and cantleyine (6) [7] were confirmed by spectroscopic analysis.

\section{GENERAL EXPERIMENTAL PROCEDURES}

CC was run on silica gel $60(40-63 \mu \mathrm{m})$. TLC was performed on aluminum and glass plates pre-coated with silica gel $60 \mathrm{~F}_{254}$ (Merck). ${ }^{1} \mathrm{H}$ NMR and ${ }^{13} \mathrm{C}$ NMR and $2 \mathrm{D}$ NMR spectra were determined in $\mathrm{CDCl}_{3}$ (JEOL JNMFX400), UV spectra were recorded on a Shimadzu UV-160A spectrophotometer using $\mathrm{MeOH}$ as solvent. MS was obtained

*Address correspondence to this author at the Department of Chemistry, Faculty of Science, 50603 University Malaya, Kuala Lumpur;

E-mail: mehranfadaie_n@yahoo.com with Agilent 6530 . The IR spectru was measured by FT-IR: pelkin-elmer RX 1 (fourier transform intra-red) spectrometer for frequencies $4000-400 \mathrm{~cm}^{-1}$.

\section{COLLECTING OF PLANT MATERIAL}

The plant materials (barks) of Rauvolfia reflexa (KL 4900) were collected from Kelantan The botanical identification was made by Mr.Teo Leong Eng, Faculty of Science, University of Malaya. Voucher specimens are deposited in the Herbarium of Chemistry Department, University of Malaya.

\section{EXTRACTION AND ISOLATION}

The extraction of the plant $(2.0 \mathrm{~kg})$ was carried out by extracted exhaustively with hexane for 48 hours to removed non-polar organic compound, waxes and fats. Then the extract was dried on the rotary evaporator. The plant material was dried and wetted with $10 \%$ ammonia solution and left for overnight. They were then re-extracted successively with dichloromethane $\left(\mathrm{CH}_{2} \mathrm{Cl}_{2}\right)$ and methanol $(\mathrm{MeOH})$. After removal of the solvents, the hexane crude extract $(1.2 \mathrm{~g})$, dichloromethane (15 g) and methanol (15 g) were obtained.

\section{MATERIALS AND METHODS}

\section{Cell Culture}

In this study, all cells used were obtained from American Type Cell Collection (ATCC) and maintained in a $37^{\circ} \mathrm{C}$ incubator with $5 \%$ of $\mathrm{CO}_{2}$ saturation. WRL-68 normal hepatic cells were maintained in Dulbecco's modified Eagle's medium (DMEM) whereas A549, non-small cell human lung adenocarcinoma epithelial cells; MCF-7, human breast adenocarcinoma cells and PC-3, prostate adenocarcinoma cells were maintained in Roswell Park Memorial Institution1640 media (RPMI-1640). Both media were supplemented with $10 \%$ of fetal bovine serum (FBS) [8].

\section{Cellular Viability}

The above mentioned cell lines were used to determine the inhibitory effect of dichloromethane $\left(\mathrm{CH}_{2} \mathrm{Cl}_{2}\right)$, methanol 
<smiles>CC(=O)C12COCCN(C)C1c1c([nH]c3ccccc13)C2C</smiles>

1<smiles>C/C=C1/CN2CCC3(C(C)=O)CC1CC(O)(C2)C3C</smiles>

2<smiles>CC(=O)OC1CC2CCC1N1C(=C(C)C)CCC21</smiles>

3<smiles>COc1cc2[nH]c3c(c2cc1OC)CCN1COC=C(C(C)=O)C(C)C3C1</smiles><smiles>COc1ccc2c3c([nH]c2c1)C1CC2C(C=COC(=O)c4cc(OC)c(OC)c(OC)c4)CC3CC2C(OC)C1C(C)=O</smiles>

5<smiles>CC(=O)c1cncc2c1CC(O)C2C</smiles>

Fig. (1). Indole alkaloids isolated from the bark of Rauvolfia reflexa.

Table 1. Shows the Effect of Crude Extracts ( $\mathrm{MeOH}, \mathrm{CH}_{2} \mathrm{Cl}_{2}, \mathbf{G 2 5}$, Thymoquinone) on Two Cell Lines (MCF-7 and WRL68) Expressed as EC50 Values in 24 Hours MTT Assay

\begin{tabular}{|c|c|c|}
\hline \multicolumn{2}{|c|}{ Cell line } & \multicolumn{2}{|c|}{ WRL-68 } \\
\hline EC50 \pm S.D. $(\boldsymbol{\mu g} / \mathbf{m l})$ & $>200$ & 12.51 \\
\hline \hline MeOH crude extract & 20.10 & 11.95 \\
\hline $\mathrm{CH}_{2} \mathrm{Cl}_{2}$ crude extract & 19.65 & 33.89 \\
\hline G25 & $\sim 5.106$ & $\sim 8.517$ \\
\hline Thymoquinone & & \\
\hline
\end{tabular}

$(\mathrm{MeOH})$ crude extracts compare with the standard compounds (G25 and Thymoquinone), on cell growth using MTT assay [9]. This calorimetric assay is based on the conversion of yellow tetrazolium bromide (MTT) to purple formazan derivatives by mitochondrial succinate dehydrogenase in viable cells. To measure cell viability, cells were seeded at a density of $1 \times 10^{5}$ cells $/ \mathrm{ml}$ in a 96-well plate and incubated for 24 hours at $37^{\circ} \mathrm{C}$ with $5 \%$ of $\mathrm{CO} 2$. Cells were then treated with the test agents in the next day and incubated for another 24 hours. After 24 hours, $10 \mu \mathrm{l}$ of MTT solution at $5 \mathrm{mg} / \mathrm{ml}$ was added to each well and then the plates were incubated for another 4 hours at $37^{\circ} \mathrm{C}$. then, water-insoluble formazan was dissolved by adding $100 \mu \mathrm{l}$ dimethyl sulfoxide (DMSO) to each well. To finish, optical density (OD) was monitored at $570 \mathrm{~nm}$ as a reference wavelength using. Results were expressed as a percentage of control giving percentage cell viability after 24 hours exposure to test agents. The potency of cell growth inhibition for each test agent was expressed as an inhibitory concentration 50 value $\left(\mathrm{IC}_{50}\right)$. Viability was defined as the ratio (expressed in percentage) of absorbance of treated cells to untreated cells [10].

\section{Statistical Analysis}

Each experiment was performed at least three times. Results are expressed as the mean value \pm standard deviation (SD).

\section{CONFLICT OF INTEREST}

The authors confirm that this article content has no conflicts of interest.

\section{ACKNOWLEDGEMENTS}

This research is supported by High Impact Research Grant UM-MOHE UM.C/625/1/HIR/MOHE//SC/09 from the Ministry of Higher Education Malaysia.

\section{REFERENCES}

[1] Lucilia, K.; Raquel, B.; Ingrid, K. Indole alkaloids from Rauvolfia bahiensis A.DC. (Apocynaceae). Phytochemistry, 2002, 30, 315320 .

[2] Massiot, G.; Boumendjel, A.; Nuzillard, J.M.; le men-Olivier, L. Alkaloids from Alstonia undulifolia. Phytochemistry, 1992, 31, 1078-1079. 
[3] Massiot, G.; Lavaud, C.; Vercauteren, J.; Le men-Olivier, L.; Anthony, A. Rearrangement of two indole alkaloids in trifluoroacetic acid: desformocorymine and dihydrocorymine. Helv. Chim. Acta., 1983, 66, 2414-2430.

[4] Cesar, V.F.B.; Jan, S.; Robert, V.; Sandra, B.; Amelia, T.H. Indole alkaloids from Rauvolfia sellowii. Phytochemistry, 1996, 41, 969973.

[5] Nauvia, M.; Ivo, J.C.V.; Jan, S.; Leda, M.; Raimundo, B.F. Darcyribeirine, a novel pentacyclic alkaloid from Rauvolfia grandiflora Mart. Tetrahedron Lett., 2002, 43, 1783-1787.

[6] Azeem, S.; Wasif, K.; Ataullah, M.; Ahmad, I. Characterization of oxidation products of Rauvolfia alkaloids. Pak. J. Pharm. Sci., 2005, 18, 33-35.
[7] Dasilva, T.M.S.; Dasilva, B.A.; Mukherjee, R. The monoterpene alkaloid cantleyine from strychnos trinervis root and its spasmolytic properties. Phytomedicine, 1999, 6, 169-176.

[8] Jennifer, L.G.; Doglas, Y. Strain-specific differences in formation of apoptotic DNA ladders in MCF-7 breast cancer cells. Cancer Lett., 1999, 144(1), 31-37.

[9] Bernas, T,; Dobrucki, J. Mitochondrial and nonmitochondrial reduction of MTT: interaction of MTT with TMRE, JC-1, and NAO mitochondrial fluorescent probes. Cytometry, 2002, 47(4), 236-242.

[10] Mosmann, T. Rapid colorimetric assay for cellular growth and survival application to proliferation and cytotoxicity assays. $J$. Immunol. Methods, 1983, 65, 55-63.

Received: May 29, 2013

Revised: September 06, 2013

Accepted: September 18, 2013

(C) Fadaeinasab et al.; Licensee Bentham Open.

This is an open access article licensed under the terms of the Creative Commons Attribution Non-Commercial License (http://creativecommons.org/licenses/by$\mathrm{nc} / 3.0 /$ ), which permits unrestricted, non-commercial use, distribution and reproduction in any medium, provided the work is properly cited.a 